\title{
Gaulish Galo
}

\author{
Alex Mullen \\ University of Nottingham \\ alex.mullen@nottingham.ac.uk \\ Coline Ruiz Darasse \\ Université Bordeaux Montaigne, \\ Institut Ausonius / UMR 5607 CNRS \\ coline.ruiz-darasse@u-bordeaux-montaigne.fr
}

\begin{abstract}
Gaulish is a language in the Celtic language family, documented in Gaul (France and surrounding territories) from around the $2^{\text {nd }}$ century $\mathrm{BC}$ and through the Roman period. It is transmitted primarily in Greek (Gallo-Greek) and Latin (Gallo-Latin) script, with a small number of Gaulish texts also attested in the Etruscan alphabet in Italy (Gallo-Etruscan) and with Gaulish names found in Iberian script. In this article we detail current knowledge of the linguistic content, context and classification of Gaulish, and consider the epigraphic corpus, naming practices, writing systems and the cultural interactions that shape this material. Finally, we discuss the future challenges for the study of Gaulish and some of the work that is underway which will drive our research in the $21^{\text {st }}$ century.
\end{abstract}

Keywords: Continental Celtic. Cultural contacts. Epigraphy. Gaul. Gaulish. Gallo-Greek. Gallo-Latin. Onomastics. Writing systems.

Resumen: El galo es una lengua perteneciente a la familia celta, que está documentada en la Galia (Francia y los territorios adyacentes) desde aproximadamente el siglo II a. C. y a lo largo del período romano. Esta lengua se escribió principalmente en alfabeto griego (galo-griego) y latino (galo-latín), aunque también se cuenta con un pequeño número de textos en alfabeto etrusco en Italia (galo-etrusco) y de nombres galos en escritura ibérica. En este artículo damos cuenta de nuestro conocimiento lingüístico, el contexto y la clasificación del galo, y consideramos el corpus epigráfico, las fórmulas onomásticas, los sistemas de escritura y las interacciones culturales que conforman este material. Finalmente, planteamos los desafíos futuros para el estudio del galo y algunos de los trabajos en curso que impulsarán nuestra investigación en el siglo XXI.

Palabras clave: Celta continental. Contactos culturales. Epigrafía. Galia. Galo. Galo-griego. Galo-latín. Onomástica. Sistemas de escritura.

Recepción: 19.08.2019 | Aceptación: 08.03.2020

Funding: Mullen's work receives funding from the European Research Council (ERC) under the European Union's Horizon 2020 research and innovation programme under grant agreement No. 715626 (project 'LatinNow'). Coline Ruiz Darasse is part of the LaScArBx (LabEx ANR-10-LABX-52) and PI of the RIIG (ANR-19-CE27-0003). 


\section{Overview and state of the art}

\subsection{Language context and classification}

Gaulish belongs to the Celtic branch of the Indo-European family tree and is attested epigraphically primarily in the last two centuries BC in Greek script and the last century $\mathrm{BC}$ and the Roman imperial period in Latin script. ${ }^{1}$ The Celtic languages show distinctive developments from their Indo-European roots for example loss of Indo-European ${ }^{\star} / \mathrm{p} /$ in most contexts and the development of Indo-European ${ }^{*} / \mathrm{g}^{\mathrm{w}} /$ into $/ \mathrm{b} / .^{2}$ The Celtic branch is further sub-divided in two main ways. For geographical reasons, the languages are split between what is called Continental Celtic, comprising Gaulish in Gaul, Celtiberian in Spain ${ }^{3}$ and Cisapline Celtic ${ }^{4}$ (Lepontic and Cisalpine Gaulish) in northern Italy (map 1) and Insular Celtic, namely the languages of the British Isles (including Breton, the result of migration from Britain). There is ongoing debate about the linguistic interrelationships of the Celtic languages, a complex problem which is compounded by patchy evidence and language contact phenomena $(\$ 2.1)$.

Gaulish is commonly used to refer to the Celtic spoken in Gaul on the non-Italian side of the Alps, in the Tres Galliae and Gallia Narbonensis, with some Gaulish attested beyond this region apparently due to movement of people (e.g. Gallo-Etruscan in Italy) or objects. Gaul is an area which covers, at its greatest extent, modern day France, Belgium, Luxembourg, most of Switzerland, northern Italy, and parts of the Netherlands and Germany. Probably the concept 'Gaul' did not mean much to the majority of its inhabitants, especially in the Iron Age and early Roman periods. The archaeological remains indicate a high degree of regional variation in the so-called 'La Tène' material culture. ${ }^{5}$ The question whether Gaulish unified the people of this area, and Celtic this

1 Some inscriptions in Gaulish are written in the Etruscan alphabet in Italy (so-called Gallo-Etruscan inscriptions). These are not discussed here: the small corpus can be found in RIG II.1.

2 For general introductions to Celtic languages, see Ball \& Müller 2010; Russell 1995; Sims-Williams 1998.

3 See F. Beltrán and C. Jordán's chapter in this volume.

4 See D. Stifter's chapter about Cisalpine Celtic in this volume.

5 Named after the famous site in Switzerland, La Tène is a label which links it to similar material culture found in other parts of the ancient world from the Iberian peninsula to eastern Europe and which has sometimes unquestioningly been linked to the language family and named 'Celtic'. 
area with others beyond it, must be approached with caution: the fact that linguists can classify the linguistic resources as 'Gaulish' and 'Celtic' does not mean the ancient communities could do the same and we should be wary of applying the potentially anachronistic view of 'one language, one nation'. Speakers of Celtic languages might have understood one another more easily than they did speakers of non-Celtic languages such as Iberian, but we should not automatically assume any deeper links. Indeed, groups in northern Gaul may have been closer linguistically and culturally to those of southern Britain than to those of southern Gaul and we know that there was regular cross-Channel communication and movement. ${ }^{6}$

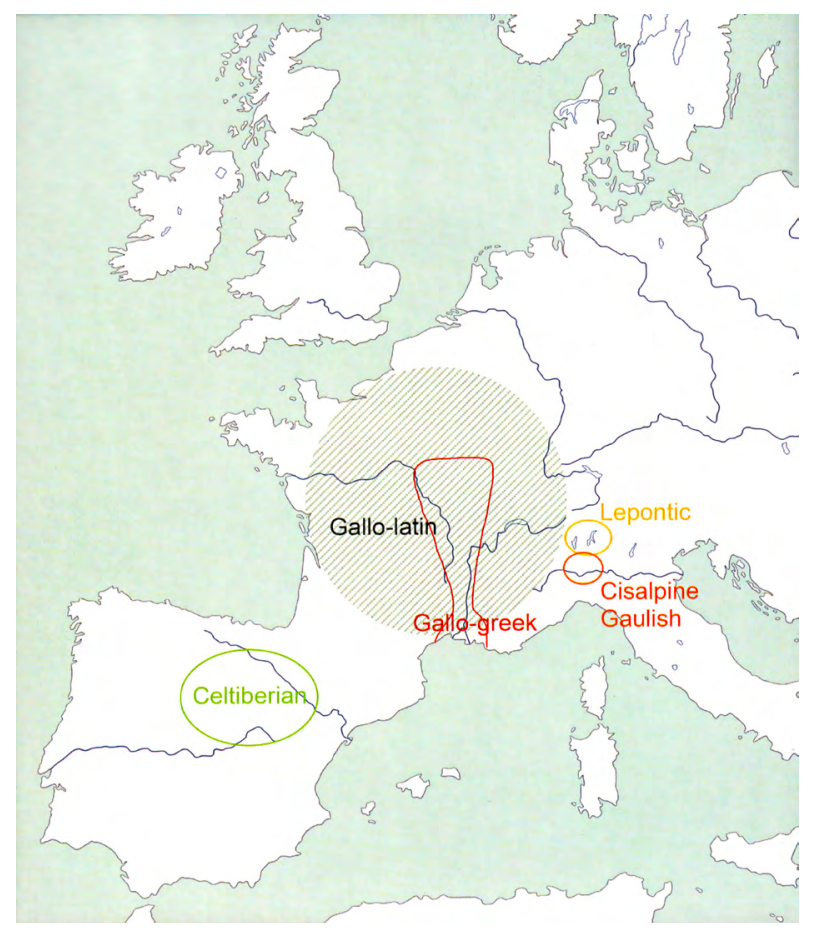

Map 1. The Celtic epigraphic zones (source: Mullen \& Ruiz Darasse 2018, map 1).

This Gaulish world was composed of dozens of complex, sometimes fractious and migrant communities, whose 'tribal' names have largely been transmitted to us by the Roman elite, most famously in the first-century BC accounts of Caesar. ${ }^{7}$ These early texts may well have misrepresented (deliberately or not), and fixed at points in time, some of the groupings; the precise

6 See Champion 2016. For the possibility of Gaulish in Britain, see Mullen 2007.

7 Caesar, De bello Gallico. 
composition and interaction of the communities are still not fully understood and require cautious interpretation of archaeological remains in combination with epigraphic and literary testimonies.

The Celtic-speaking communities are closely imbricated with others across the Mediterranean and the north-west. Gallo-Greek shows signs of interaction with a mixed Mediterranean world and Gallo-Latin is heavily influenced by Roman language and culture, producing bilingual and mixed texts ( $\$ 1.6)$. In the south-west of Gaul, Gaulish-speaking communities do not seem to write in their own language but are involved in the Iberian epigraphic $\operatorname{record}^{8}$ (especially, for example, at Ensérune, see fig. 1).

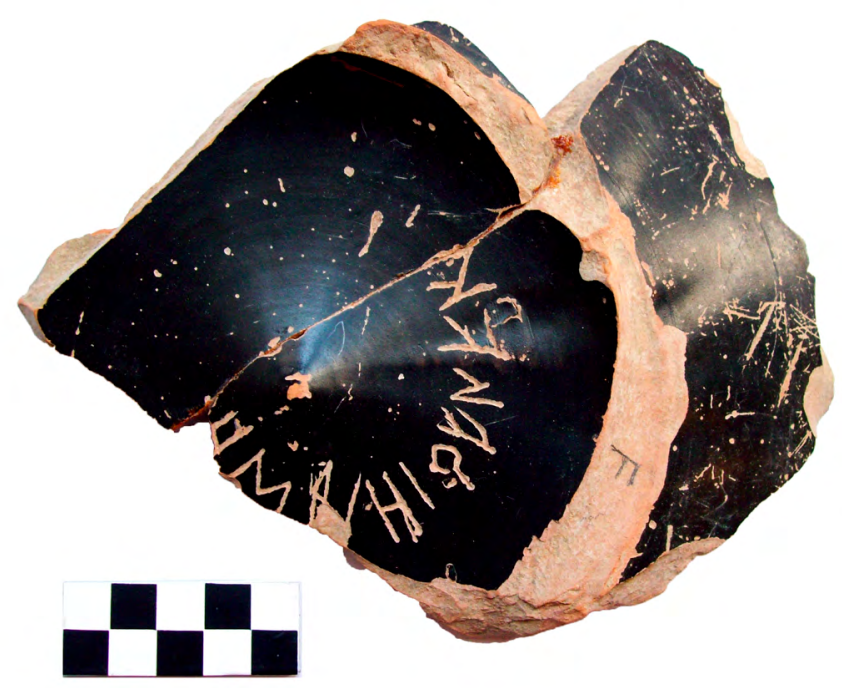

Fig. 1. A Gaulish name written in northeastern Iberian script found in Ensérune (Hérault, France) (photo: C. Ruiz Darasse).

\subsection{Historiography and state of the art}

Celtic studies began in the $16^{\text {th }}$ century with George Buchanan, who relied extensively on place names, followed by figures such as Paul-Yves Pezron and Edward Lhuyd in the $17^{\text {th }} \cdot{ }^{9}$ A surge in interest in the Gaulish language

8 Texts in Palaeohispanic languages and scripts are collected in the Monumenta Linguarum Hispanicarum $(M L H)$ series published by J. Untermann between 1975 and 1997, now updated in the online Heperia database $(B D H)$, see also Untermann 1992.

9 See Collis 2003, 34-52. 
and its speakers can be placed at the end of the $19^{\text {th }}$ century, following the archaeological excavation campaigns undertaken in 1861 by Napoleon III to find the remains of the Roman siege of Alesia. The archaeology of the Celtic world, and especially that of Gaul, has been shaped by scholars such as Joseph Déchelette, author of the first Manuel d'archéologie préhistorique, celtique et gallo-romaine (1908-1914). For the language, we can cite early authors such as Henri d'Arbois de Jubainville (1827-1910), Joseph Loth (1847-1934) and Georges Dottin (1863-1928), author of La langue gauloise: Grammaire, Textes et Glossaire (1918), which was largely based on epigraphic data. At that time, only c. 60 inscriptions were known; we now have several hundred more. Other out-dated works on Gaulish which remain regularly cited, but are often criticized for their over-capaciousness are Holder 1896-1913 and Whatmough 1970.

Modern scholarship on Gaulish language and inscriptions has been largely Francophone, with numerous works by Michel Lejeune (1907-2000), Robert Marichal (1904-1999), who was mainly interested in the La Graufesenque graffiti, Paul-Marie Duval (1912-1997), Michel Bats, Xavier Delamarre and Pierre-Yves Lambert. Delamarre's Dictionnaire de la langue gauloise (2018) offers a compendium of Gaulish words from all sources, including those found in the Latin and French languages, examples transmitted by medieval glossaries, and from the epigraphic record. Lambert has produced three editions of the influential La langue gauloise (2018). Books on Gaulish language and epigraphy are less common in other languages, though see now, Meid 2014; Mullen 2013a; Mullen \& Ruiz Darasse 2018, 2019.

Before our epichoric epigraphic sources built up substantially, studies of Gaulish relied heavily on names of persons and places, transmitted through a range of sources, including medieval documents, classical texts and epigraphy. Gaulish and Celtic names have continued to attract a great deal of scholarship since they are widespread and numerous, unlike the inscriptions (for excellent examples of this work, see Evans 1967; Schmidt 1957; Delamarre 2007; 2012; Sims-Williams 2006; Raybould \& Sims-Williams 2009). ${ }^{10}$

The reference corpus of the epichoric epigraphy, named RIG (Recueil des Inscriptions Gauloises), was published between 1985 and 2002. It includes five volumes: the first, $R I G \mathrm{I}$, is based solely on the alphabet used, i.e. Gallo-Greek;

10 There is also a regularly updated Celtic Personal Names of Roman Britain (CPNRB) at $<$ http://www.asnc.cam.ac.uk/personalnames/> (last accessed 27/3/2020), which is important given the lack of Celtic language inscriptions from Britain. 
the other four have a functional or material logic: Gallo-Etruscan and Gallo-Latin texts on stone, RIG II.1; calendars, RIG III; coins, RIG IV; and most recently, Gallo-Latin inscriptions on instrumentum domesticum, RIG II.2.

$R I G$ I has been updated with supplements such as the series of articles "Compléments gallo-grecs" in Études Celtiques by Lejeune and Lambert between 1988 and 2003 (see e.g. Lambert 2003). Gallo-Greek is well-endowed with articles on individual inscriptions, groups of inscriptions or specific linguistic features (e.g. in the academic journals Etudes celtiques, Keltische Forschungen, Studia Celtica). Michel Bats has written several times on the epigraphies of southern Gaul. ${ }^{11}$ Books are much less common, though see now the monograph which treats Gallo-Greek epigraphy in its cultural context, Mullen 2013a. RIG II.1 and RIG II.2 must be supplemented with Lambert 2008. The site of La Graufesenque, which offers many texts containing Gaulish is well served by Marichal 1988 ( $\$ 1.6)$. Again, Gallo-Latin has attracted multiple specialist articles, for example the collection in Etudes Celtiques 39 (2013) on the Chartres lead text.

RIG III is dedicated to the presentation of the two known Gaulish calendars: that of Coligny and the (even more fragmentary) example of Villars d'Héria. The first, found in 1897 by chance in a field pit with a statue with Apollo-type attributes, is currently kept at the Gallo-Roman Museum of Fourvière in Lyon. This calendar seems to involve lunar cycles and links astronomical phenomena with religious and social events, demonstrating the persistence of indigenous linguistic and cultural traditions in Gaul in the $2^{\text {nd }}$ century AD. Sadly its fragmentary state and complexity hinders researchers' understanding, leaving scope for imaginative interpretations. ${ }^{12}$ Its reconstructed size is $1,48 \times 0,90 \mathrm{~m}$, and fully extant it would be the longest inscription in the Gaulish language known to date.

The Gaulish coin legends are collected in RIG IV. For early coinage from southern France, see Feugère \& Py 2011 and for examples in the Bibliothèque nationale, see Muret \& Chabouillet 1983. Work is currently ongoing by E. Hiriart to update our resources. He has already published the corpus of the coins with crosses (Hiriart 2017).

11 See, for example, Bats 1988; 2011 a.

12 See, for example, Olmsted 1992; Zavaroni 2007. 
There are multiple websites on Celtic matters, many containing information which is not scholarly. The website of L'Encyclopédie de l'arbre celtique, ${ }^{13}$ is a reliable offering for the general public which contains inscriptions from across the Celtic-speaking world (including from $R I G$ ) and bibliography relating to the Gaulish language. In the near future RIIG (Recueil informatisé des inscriptions gauloises) will be released online (https://riig.huma-num.fr/). It will constitute a new editio of Gaulish inscriptions, updating RIG and using Linked Open Data. Beyond the completion and modernization of previous editions, the aim is to publish each inscription again with up-to-date contextualization, readings, archaeological and linguistic bibliography.

\subsection{The language}

In terms of phonology, most of the signs identified in the inscriptions do not present any serious problem of interpretation. There is some lingering uncertainty as to the length of vowels and how this may change over time, since Gallo-Greek seems to note their timbre but not their length. ${ }^{14}$ The main areas of ongoing phonological debate, the 'tau gallicum' and accentuation, will be raised in $\$ 2.1$.

Nominal morphology is relatively well-known for Gaulish despite the incomplete data. We can reconstruct the declension of about ten stems $(-o ;-\bar{a}$; $-i$; - $u$; - $r$-; - $n$-; in dental occlusives (voiceless); in dorsal occlusives (voiced); in sibilants). ${ }^{15}$ The lengthy text of the Larzac (Aveyron) lead tablet, concerning magic and women, has helped our reconstruction of the $\bar{a}$-stem forms, which, in the course of their development in the Roman period, seem to have been influenced by $\bar{\imath} / i \bar{a}$-stem nouns thus explaining the alternative forms in the $\bar{a}$-stem singular (-an, -im (accusative), -as, -ias (genitive); - $a i,-i$ (dative)). We cannot be certain that a dual case exists. ${ }^{16}$

Verbal morphology is more poorly understood for Gaulish than nominal. We know three tenses (present, ${ }^{17}$ preterite, future/desiderative forms ${ }^{18}$ ) and

$13<$ http://encyclopedie.arbre-celtique.com> (last accessed 27/3/2020).

14 RIG I, 441-442.

15 RIG I, 449-450.

16 Lambert 2018, 54.

17 immi 'I am' on a bowl from Les Pennes-Mirabeau (Bouches-du-Rhône), RIG I, G-13.

18 marcosior 'I will be ridden/ride like a horse'?, on a racy spindle whorl from Autun (Saône-et-Loire), RIG II.2, L-117. 
at least three modes (indicative, subjunctive ${ }^{19}$ and imperative $\mathrm{e}^{20}$ ). It is possible that there is also an optative. ${ }^{21}$ Three verbs commonly recur in Gaulish, all three are preterites. Two of them are verbs of dedication and appear in votive formulas: dede 'he gave' (probably closely related to Latin dedit and Oscan deded, both Italic languages) which is restricted to Gallo-Greek and to a very specific formula (dede bratou dekantem ${ }^{22}$ ) and ieuru 'he dedicated. The third verb is avot 'he made', mostly present in marks of craftsmen (for example in signatures on moulds or stamps).

The syntax of Gaulish is not understood in detail: we can often work out how sentences fit together, but could not yet write an in-depth description of the syntax of the language, despite some excellent research. ${ }^{23}$ It is possible, for example, to identify a number of connectors, coordination and sentence structuring elements (eti or etic for example, in Chamalières RIG II.2, L-100) ${ }^{24}$ but sentence word order is not easy to specify because it is difficult to generalize from a corpus as small as that of Gaulish. As syntactic functions are marked by inflectional morphology, the Gaulish sentence could have a free order, however analysis of the dedication formulae (such as that of dede bratou dekantem as well as the dedications in ieuru) shows a preference for a subject-verb order with an object and/or a dative that can be placed more freely. As more longer texts are coming to light on, for example, sheets of metal and ceramic, and we analyse older ones better, we are constantly refining our knowledge.

The Gaulish lexicon is mainly known through onomastics (anthroponymy, theonymy, toponymy). Several types of anthroponymic composition and derivation have been identified. ${ }^{25}$ Another area from which other vocabulary has been transmitted is the world of potters (especially via the La Graufesenque graffiti). However, it is often difficult for us to determine precisely what each technical term corresponds to.

19 buet 'may he be' from Chamalières (Puy-de-Dôme), RIG II.2, L-100.

20 gabi 'take' on spindle whorl from Saint-Révérien, Nièvre, RIG II.2, L-119.

21 nitinxsintor on the lead tablets from Larzac, a preverb plus third person deponent optative, related to Latin defigo 'I fix', RIG II.2, L-98.

22 For a detailed description, see Mullen 2013a, 189-218.

23 Eska 2007.

24 For particles in the Chamalières text, see Eska 1997, for particles in Celtic more generally, see Schrijver 1997.

25 See Evans 1967; Lambert 2018, 28-40; Schmidt 1957. 


\subsection{The epigraphy: location and chronology}

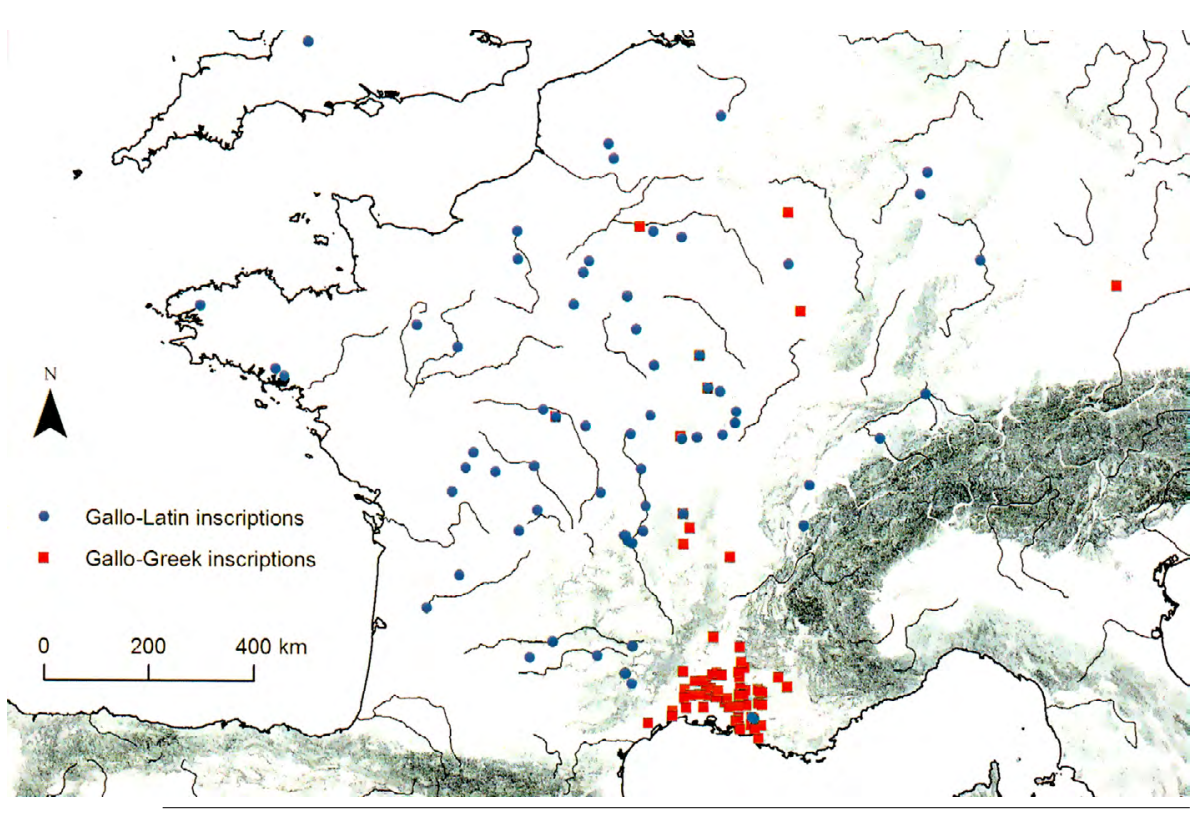

Map 2. Sites producing Gallo-Greek and Gallo-Latin inscriptions (Alex Mullen). ${ }^{26}$

Gallo-Greek is Gaulish written in the Greek alphabet (map 2). Traditionally the texts were dated from the $3^{\text {rd }}$ century BC to the Augustan period. Archaeologist Michel Bats has reassessed the materials and has suggested that the earliest clearly Gaulish inscription on ceramic can be dated to the last quarter of the $2^{\text {nd }}$ century BC (Le Baou-Roux; Lejeune 1994, G-526) and the earliest lapidary inscription to the $2^{\text {nd }}$ century BC (Atila's stele; Sernhac, RIG I, G-218, dating to $150-125 \mathrm{BC}) .{ }^{27}$ These dates provide only a terminus ante quem for the creation of Gallo-Greek, though most of the material does seem to fit in the last two centuries BC and the first century AD. Gallo-Greek is largely attested in the lower Rhone basin, stretching nearly to Marseille to the east and as far as Montagnac (RIG I, G-224) to the west - though a new inscription has recently been found a further $c$. 40 kilometres to the west at Ensérune (Ruiz Darasse 2020) and there is a possibly Gallo-Greek text on lead from Elne

26 Note that this map does not indicate the distribution of inscriptions across the sites. Also not included are numerous find-spots of Gaulish stamps and signatures on objects not found at their point of manufacture.

27 See Bats 1988; 2011a for details and Mullen 2013a, 106-107, for a summary. 
(Lejeune 1960). There are a few Gallo-Greek producing sites in the central-eastern part of France, largely along river routes, with Bibracte (Mont-Beuvray, RIG I, G-235-G-255) and Alesia (Alise-Sainte-Reine, RIG I, G-256-G-270) offering significant outputs.

The other main epigraphic medium for Gaulish is Latin script (map 2). The Gallo-Latin texts seem to appear from around the Caesarian period onwards. Gallo-Latin has generally been regarded as an early imperial phenomenon, though several of our archaeologically dated examples can be dated to later in the Roman period. To date, the latest evidence of a text in Gaulish is the Châteaubleau tile (RIG II.2, L-93) which has been placed in the $3^{\text {rd }}-4^{\text {th }}$ century AD; the silver plate from Poitiers (RIG II.2, L-110, $5^{\text {th }}$ century AD?) may not be a Celtic text strictly speaking. In fact, we do not know with any degree of certainty at what point the Gaulish language stopped being spoken; there are many Gaulish names transmitted in later Latin documents, but that may say little about language more generally. It is likely that in some isolated communities, or in groups with particularly close associations between language and identity, the language may have survived longer in some form, perhaps alongside Latin, but it seems likely that very little, if any, Gaulish was spoken after the $5^{\text {th }}$ century $\mathrm{AD} .^{28}$

\subsection{The epigraphy: origins, text types and developments}

A complex debate has arisen on the origins of Gallo-Greek epigraphy. The script itself does not contain any diagnostic features as it is standardly used to write Koine Greek throughout the Greek world in this period. Linguists and epigraphers have traditionally assumed that the script was borrowed from the major Greek colony in the area, Massalia (modern Marseille), founded in c. $600 \mathrm{BC} .{ }^{29}$ Interesting issues must be considered however. Why was there such a long time-lag before Gallo-Greek appears in the very late third century or second century BC, when Greek colonists settled in 600 BC? Why are there no Gallo-Greek inscriptions in Greek settlements? Why are there no Greek names or much evidence for linguistic interaction between the Greek and Gaulish groups within the Gallo-Greek record? A combination of the following factors: a) the Phokaian Greek colonists were to a large extent

28 On the problems of understanding the meaning of terms such as lingua gallica, lingua celtica (whether referring to Gaulish or forms of regional Latin etc.), see Blom 2007. For the survival of Gaulish in the $4^{\text {th }} / 5^{\text {th }}$ century AD, see Meissner 2009-2010. 
anepigraphic (i.e. did not produce much epigraphy in their settlements in the west, or indeed in the metropolis, Phokaia, in Asia Minor), b) the diffusion of Gallo-Greek does not centre on the Greek settlements peppered along the coast but rather on the lower Rhone basin, and c) the timing of the adoption and spread of Gallo-Greek from the second century BC, has encouraged some scholars to view the adoption and spread of local epigraphy as linked to the steady rise of Roman influence across the western Mediterranean and interactions between a diverse Mediterranean community. ${ }^{30}$ The Phokaian Greek colonists undoubtedly played a part in this community, but we should not take for granted that interaction with them at Marseille signalled the creation of Gallo-Greek. Recent analysis has raised the possibility that Greek handwritten documents, using cursive $\mathrm{C}, \Theta, \omega$ rather than $\Sigma, \mathrm{E}, \Omega$, may have been the model for the script and that the origins may have been, at least in part, through wide-ranging economic activities with Mediterranean communities. ${ }^{31}$ Material from third-and second-century BC Martigues (Bouches-du-Rhône), an indigenous settlement on the south coast, may provide evidence on ceramic from a transitional period where writers were experimenting with how to produce written Gaulish. Some of the inconsistencies in the Gallo-Greek record, and, in particular, the different options for notating the 'tau gallicum', may even encourage us to consider the possibility of more than one point of origin for Gallo-Greek.

The census of Gaulish inscriptions made recently as part of the AELAW network's activities counted the following published texts: for Gallo-Greek, coin legends from 70 mints, over 320 graffiti on ceramic, 76 epitaphs and other inscriptions on stone (mainly stelae), and 11 inscriptions on metal; for Gallo-Latin, coin legends from 270 mints, over 250 graffiti on ceramic, 17 epitaphs and other inscriptions on stone, and 33 inscriptions on metal (mostly on lead (13) and bronze (15)). Much of the documentation that has reached us in the Gaulish language is from the funerary and religious sphere, whether dedications or magical texts. We know, especially from the Gallo-Greek corpus, several dozen stelae mentioning only the name of the deceased (fig. 5). But an even larger part of the documentation is composed of names designating the owner of the object. We can thus consider that we are dealing with an epigraphy that is largely of a private nature.

\footnotetext{
30 Mullen 2013a.

31 Mullen 2013a, 101-106.
} 
It is clear that the epigraphic practice in Latin script appears with a wider range of functions and on a greater range of materials than in Greek script, including spindle whorls, fire-dogs and tiles. Ceramic remains the preferred medium overall for Gaulish inscriptions whether in Greek or Latin script. The Gallo-Latin corpus contains some lengthy texts, to which nothing currently compares in Gallo-Greek, for example the magical texts from Larzac ( $R I G$ II.2, L-98) (fig. 2) and Chamalières (RIG II.2, L-100), the calendars from Coligny (Ain) and Villars-d'Héria (Jura) (RIG III), the tile from Châteaubleau and a number of detailed firing lists from the pottery at La Graufesenque (Marichal 1988). There are proportionally also fewer lapidary inscriptions in the Gallo-Latin corpus than in the Gallo-Greek. It is possible that many of these Gallo-Latin inscriptions can be assigned to the religious domain. Some religious dedications in Gallo-Latin are unusual and hard to parallel in other corpora, such as the famous pillar of the nautes (RIG II.1, L-14) or the Mercury of Lezoux (RIG II.1, L-8). The Gaulish language may have been maintained relatively late in religious contexts, magical practices and in the field of popular superstition, as illustrated by the defixiones. There are currently around fifteen of them, mostly from the Arverni and Ruteni regions.

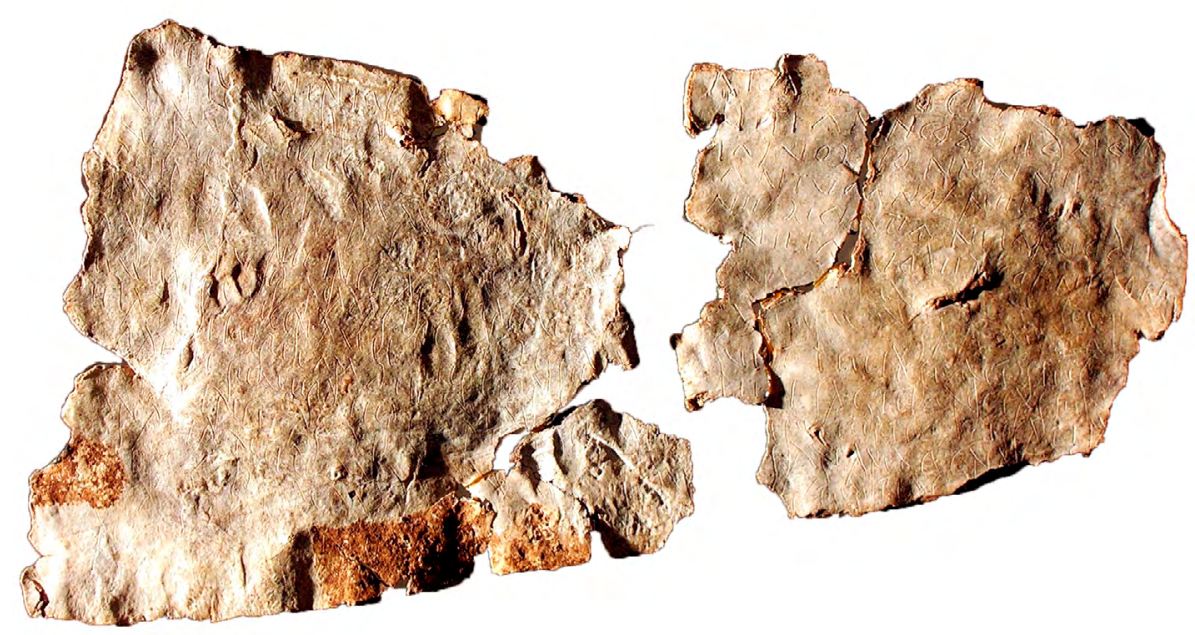

Fig. 2. Lead tablet inscribed in Gallo-Latin from Larzac (RIG II.2, L-98) (Wikicommons). 
Two examples of very similar texts from Vaison-la-Romaine and AliseSainte-Reine will indicate some differences between the two main Gaulish epigraphic corpora (figs. 3-4). The first is a lapidary dedicatory inscription of $25 \times 31 \mathrm{~cm}$ and seems to have been cut from a larger original piece, about which we know nothing. The stone was found in Vaison-la-Romaine in the $19^{\text {th }}$ century and the context is, as with many of these inscriptions found before modern developments in archaeological practice, sadly lost. It dates to the $2^{\text {nd }}$ or $1^{\text {st }}$ century BC, based on comparanda, and reads СЕГОМАРОC / OYI $\Lambda$ ONEOC / TOOYTIOYC / NAMAYCATIC / EIWPOY BH $\Lambda$ H/CAMI COCIN / NEMHTON 'Segomaros, son of Villu, citizen of Namausus (Nîmes), dedicated this grove to Belesama. The second lapidary dedicatory inscription comes from Alise-Sainte-Reine (Côte-d'Or) and was found in the $19^{\text {th }}$ century on Mont-Auxois, close to the subsequently discovered so-called 'monument of Ucuetis'. It probably dates to the $1^{\text {st }}$ century AD. The text reads: MARTIALIS DANNOTALI / IEVRV VCVETE SOSIN / CELICNON ETIC / GOBEDBI DVGIIONTIIO / VCVETIN / IN ALISIIA 'Martialis, son of Danotalos, dedicated this building to Ucuetis and with the blacksmiths who worship Ucuetis in Alisia?.

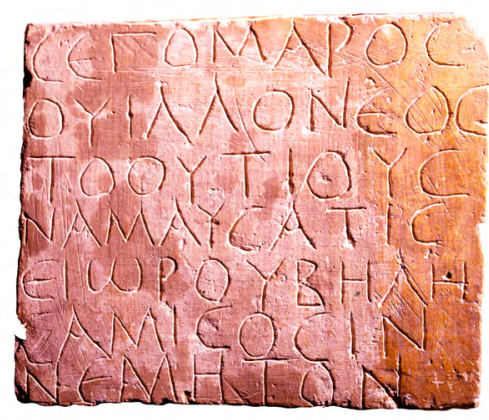

Figs. 3-4. Gallo-Greek inscription from Vaison-la-Romaine (RIG I, G-153) (Purchase of the Fondation Calvet, 1841, Musée Calvet, inv. E 25); Gallo-Latin inscription from Alise-Sainte-Reine, (II.1 L-13) (Conseil Départemental de la Côte-d’Or, Musée Alésia, dépôt du Musée Municipal d'Alise-Sainte-Reine).

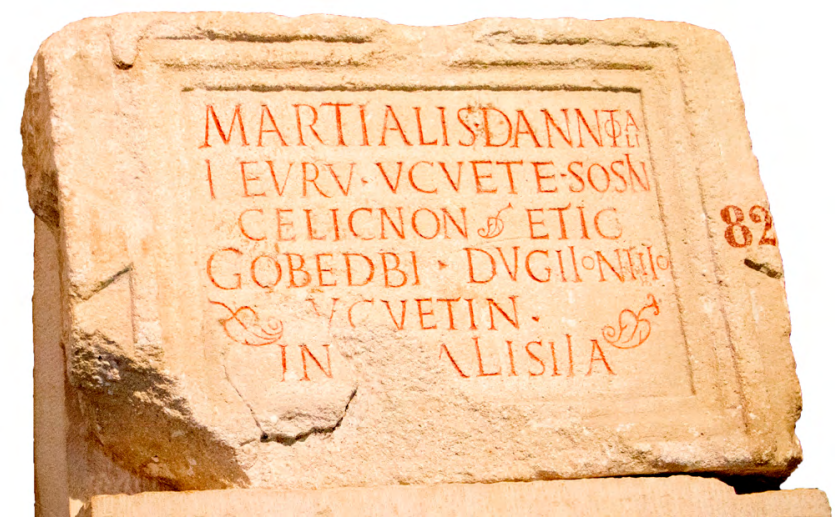


These two texts are very similar from a linguistic point of view and similar in terms of content: both are dedications by Gaulish speakers who dedicate something to a local deity, probably in both cases somewhere for the deity to reside (nemeton/celicnon). The Gallo-Greek inscription adds information about the dedicator, whilst the Gallo-Latin adds details about a local group involved and their location. The texts are quite different materially, however, with the Vaison-la-Romaine example, like the vast majority of Gaulish texts in Greek script, much more 'rustic' and simpler in style, whereas the AliseSainte-Reine text follows more explicitly 'classical' norms. It shows features of Roman epigraphy which are not so typical in Gallo-Greek examples (hederae, interpuncts, ligatures and ansate frame) and has clearly been written in an effort to demonstrate stone-cutting skill. It does not match the precise geometry of the most impressive Roman inscriptions, but it seems to have been executed with such monuments in mind. This material and visual aspect of the two epigraphies has to date been rather overlooked. Gallo-Greek offers a homogenous style of writing (there are some exceptions, for example, the Nimes (RIG I, G-203) and Saint-Côme (RIG I, G-214) inscriptions, possibly by the same stonecutter) and many fewer object types than Gallo-Latin, which seems to embrace the Roman writing habit more fully.

\subsection{Cultural and linguistic interactions}

External interactions in Gaul emanated from all around the Mediterranean basin and beyond. Edged by the Mediterranean, Channel and Atlantic Ocean, water-ways which were criss-crossed with traffic for thousands of years, Gaul always entertained multiple voices. From about the $6^{\text {th }}$ century $\mathrm{BC}$ the area enters the historical stage with the foundation of Marseille and the region becomes a meeting point for speakers of Iberian, Greek, Etruscan, Italic languages, Phoenician, Punic, 'Ligurian', Gaulish and other Celtic languages. Comparanda would suggest that the majority of these speakers were bi- or multi-lingual. External influences had an impact on the communities of Gaul; in particular, increased trade and contact provoked responses from indigenous communities, for example movements away from subsistence and increased settlement fixity. ${ }^{32}$ The settlements undergoing most rapid transformation were often those closest to the major trading routes and other points of communication, and, therefore, for example, to the maritime koine, and to 
Greek centres, ${ }^{33}$ although some indigenous settlements in the direct hinterland of Marseille seem to have experienced tense, sometimes hostile, relationships with the colony and retained distinctively indigenous facies. ${ }^{34}$ The diversity of reactions and the continuation of many local practices demonstrate that developments in Gaul reflect a combination of external and internal influences and motivations.

The Etruscan presence is felt from an early period through trade and some (limited) settlement, for example at Lattes, ancient Lattara, near Montpellier, ${ }^{35}$ a settlement, established c. $500 \mathrm{BC}$, which appears to have welcomed a range of population groups. ${ }^{36}$ One $5^{\text {th }}$ century inscription in South-Etruscan script from Lattes seems to consist of an Etruscan version of a Celtic name in the genitive: Ucial. ${ }^{37}$ Another inscription dating to between the $5^{\text {th }}$ and $4^{\text {th }}$ centuries BC from Ensérune demonstrates interactions between Etruscans and Celtic-speaking populations, recording a Celtic feminine name written in the genitive in the Etruscan alphabet: Smeraz (originally considered to be in Iberian script: $B D H$, HER.02.002 celta).$^{38}$ However, a local Celtic epigraphy in Etruscan script is not created as it is around Lake Lugano in northern Italy ('Gallo-Etruscan'). ${ }^{39}$

Palaeohispanic epigraphy in Gaul appears as ownership marks on imported ceramics and stamps on dolia, on a dozen sheets of lead, on coins, and, very rarely, on stone. The epigraphy is largely a feature of the $3^{\text {rd }}$ to $1^{\text {st }}$ centuries $\mathrm{BC}$ and rapidly disappears under the Roman Empire. A few sites produce this epigraphy: Ruscino/Château-Roussillon, Elne, Ensérune, Mailhac, Montlaurès, Pech Maho, Peyriac-de-Mer, Tourouzelle and Vieille-Toulouse. Inscriptions on imported objects have also been found on three sites (Lattes,

33 Py 2012, 113, 253.

34 See Bernard, Collin-Bouffier \& Tréziny 2010.

35 Py 1995; 2009; Belfiore 2015.

36 Colonna 1980 and Py 1995 discuss Etruscan inscriptions (in South-Etruscan script) from Lattes.

37 Colonna 2006, 665-666; De Hoz 2008, 18; Bats 2011b, 204. See Briquel et alii 2006; Colonna 2006; Gran-Aymerich 2006 for recueils of Etruscan inscriptions from Gaul, also Bats 2011b, 204-205 and Belfiore 2015.

38 De Hoz 2008.

39 See footnote 1 . The only evidence of the Lugano alphabet (used to write Lepontic and Cisalpine Gaulish) in Transalpine Gaul is the enigmatic so-called Padane drachma, see Bats 1988, 131, 141-142; Deroc 1983; Häussler 2002, 62-63; 2008, 57-59, and possibly an inscription on Campanian A ware from Baou de Saint-Marcel (Bouches-du-Rhône): ( )oidsa(i), see Bats 1988, 141-142. 
Gruissan and Aubagnan $)^{40}$ and are not evidence of a local practice of using Palaeohispanic scripts but rather of well-established contacts with the Iberian peninsula. With the exception of Ensérune which offers a corpus of nearly 400 inscriptions, none of these 'Palaeohispanic' sites provides many inscriptions.

The presence of the northeastern Iberian script in southern Gaul is one of the supporting arguments for Javier de Hoz's hypothesis that Iberian was a lingua franca particularly in the trading realm between different population groups. This view sees the origin of Iberian language and culture in Contestania, and an expansion from south to north of the language and northeastern script. ${ }^{41}$ The Palaeohispanic inscriptions from Ensérune offer an Iberian anthroponymic stock which matches that found in the Iberian peninsula (e.g. selkiteŕ $B D H$, HER.02.024) but also many Celtic personal names (e.g. katubare $B D H$, HER.02.373). ${ }^{42}$ It seems that, from the $4^{\text {th }}$ to $2^{\text {nd }}$ century $B C$, links between the Celtic and Iberian populations at this site were so close that local workers even chose the northeastern Iberian script ${ }^{43}$ although not well suited to their language, ${ }^{44}$ for their stamps on dolia. ${ }^{45}$

In the mid- $2^{\text {nd }}$ century $B C$ (between 175 and $150 / 130 \mathrm{BC}$ ), close contacts and trade between Iberian-, Latin- and Gaulish-speaking groups in Vieille-Toulouse (Haute-Garonne) are attested in Graeco-Italic amphorae marked with Levantine characters and found in wells. ${ }^{46}$ Several interpretations have been advanced for the texts linking the names with the following: quantity, date, ${ }^{47}$ price, ${ }^{48}$ lot number and, more recently, tolls. ${ }^{49}$ This appears to be a unique epigraphic group and to represent a 'processus typiquement tolosate. ${ }^{50}$ Amongst the names we find Latin names (e.g. seste/Sextius), Celtic

40 Gorrochategui 1984, 50.

41 For a recent presentation, see De Hoz 2011b.

42 Correa 1993; Ruiz Darasse 2010; De Hoz 2011a, 158-162.

43 De Hoz 2011a, 215.

44 Amongst the signs created for the dual system we should note the systematic use of certain signs to represent sounds specific to Gaulish or Latin, for example the use of the sign $<$ ŕ $>$ in the transcription of Latin and Celtic names in south-western Gaul and the north-east of the Iberian peninsula, see Ruiz Darasse forthcoming.

45 The Iberian stamps are collected in Simón 2013.

46 Vidal \& Magnol 1983; Lejeune 1983; Gorgues 2010, 309-325.

47 Lejeune 1983, 35.

48 Lejeune 1983, 36.

49 Gorgues 2010, 317.

50 Gorgues 2010, 311. 
(e.g. anbi) and Iberian (e.g. sakar). ${ }^{51}$ The texts are associated with cookware of Massaliote origin, leaving open also the possibility of resident Greek individuals. This group of texts would have remained an isolated case if new finds had not backed up the picture of multiculturalism. In the nearby Quartier Saint-Roch other inscriptions dating to $c$. 125-100 BC include Greek names also attested at Marseille in strata with inscriptions in northeastern Iberian script. ${ }^{52}$ Even if these short inscriptions cannot allow us to reach firm conclusions about the precise nature of the interactions, we can nonetheless be certain that the northeastern Iberian script was being used at Vieille-Toulouse at a relatively late period for writing Iberian (e.g. lakei) ${ }^{53}$ and for transcribing local names,$^{54}$ alongside Latin and Greek.

Although Gallo-Greek may begin with experimentation with graffiti on ceramic and be associated with trading contexts and internal settlement requirements, the lapidary development can perhaps be associated with additional factors in the evolving cultural environment of the first century BC, including increasing numbers of 'non-indigenous' individuals in the hinterland, partly due to influxes from the Italian peninsula. These incomers bring not only the notion of an 'epigraphic habit', which does not appear to have been embraced by Phokaian Greeks, but also a motivation for local expression in this new world order. The distribution of the texts supports the link: the most prolific sites for lapidary Gallo-Greek are Glanum, Nîmes and Cavaillon, all of which later become significant Roman settlements. In addition, the non-Gaulish linguistic features in these texts can be related to the Italian peninsula. We find a praetor, ПPAIT $\omega \mathrm{P}$ (RIG I, G-108), attested at Vitrolles (Bouches-du-Rhône) which indicates an interest in, at least superficially, Roman modes of organization. Similarly, the non-Gaulish names can be linked to non-Greek Italian origins (see $\$ 1.8$ )..$^{55}$ The main recurring formula, the Celtic dede bratou dekantem, probably meaning 'gave a tithe in gratitude', can

51 Editio princeps: Vidal \& Magnol 1983; Lejeune 1983.

52 Moret, Ruiz Darasse \& Verrier 2015.

53 Moret, Ruiz Darasse \& Verrier 2015, 409-410.

54 Moret, Ruiz Darasse \& Verrier 2015, 411-413, unless it is a writing exercise.

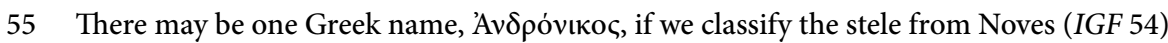
as Gallo-Greek rather than Greek. This example raises an important problematic point: the classification of Gallo-Greek inscriptions as opposed to Greek can be, in the absence of firm diagnostic linguistic features, relatively arbitrary, relying on the linguistic origins of the names themselves and the labelling of the find spot in material culture terms, see Mullen 2013a, 149-152 and 153-157, for discussion. 
be linked to influences from a Mediterranean koine, and communities from central-southern Italy provide all the elements and appropriate circumstances for contact-induced adoption. The Gallo-Greek inscription from Velleron (Vaucluse) is the only secure instance of a bilingual text involving Gaulish from southern Gaul. ${ }^{56}$ The format of the inscription appears most likely to be two masculine personal names, KAEIOC IN $\Delta$ OYTI $\Lambda$ O 'Gaius Indoutilos' (Latin + Celtic), followed by two feminine personal names, CAMO $\Lambda$ ATIC ANEKTIA 'Samolatis Anektia' (Celtic + Celtic), and an accurate transliteration of the Latin verb ualete into Gallo-Greek: OYA $\Lambda$ HTE.

Evidence for interaction between Phokaian colonists and indigenous groups was rare in the pre-Roman epigraphy, but under Roman rule some of the best evidence for linguistic and cultural interaction between Greek-named and Celtic-named individuals can be found. At the rock sanctuary known as La Tour de l'Acapte on the Presqu'île de Giens thousands of fragments of ceramic have been uncovered equating to hundreds of Greek inscriptions. ${ }^{57}$ These indicate that this simple rural sanctuary is dedicated to Aristaios and that the dedicators have a mixture of both Greek and Celtic names. ${ }^{58}$ The naming practices and formulae at the site show striking instances of negotiation between the two languages within a Greek discourse, including hybrid names, which distinguish this site in the context of south-eastern Gaul, and possibly in terms of written evidence for Celtic-Greek interaction anywhere. The sanctuary is found at a distance of around 5 kilometres from the Phokaian colony Olbia (Var), and shows Celtic-named individuals apparently intimately involved in a Greek rural cultic context. Though evidence elsewhere suggests that the Greek language was largely restricted to colonies and trading contexts, this epigraphic cache reminds us of the heterogeneity of interactions and communities and the dangers of over-generalization.

Language contact is most extensively attested in the Gallo-Latin record. ${ }^{59}$ We have already seen that the range of objects, types of writing and functions seems to expand between Gallo-Greek and Gallo-Latin, with Gallo-Latin

56 For de Velleron inscription, see Bats 2011a, 222-225; Mullen 2013a, 182-189. There may be another from Olbia, IGF 66, see Mullen 2013a, 171-173.

57 These are still not fully published, see IGF 68; Bats 2004, 16-17; Giffault \& Coupry 1990; Mullen 2013a, 243-263.

58 There are also two Latin names, see Bats 2004, 10-12; Mullen 2013a, 243-262, with table 11 for details of the names.

59 For bilingual texts in the west, see Estarán 2016. 
adopting the Roman epigraphic package more fully. There are a few texts showing mixtures of scripts and languages, for example the hard-to-interpret stele from Genouilly in central France (RIG II.1, L-4, I, G-225). At the top of the stone we read in Gallo-Latin [...T]OS VIRILIOS, likely a Celtic idionym plus adjectival patronymic in -ios. Immediately below we find, in Greek letters, $[. .$.$] TOC OYIPI \Lambda \Lambda \mathrm{IO}[\mathrm{C}]$, which seems to be a representation of the same name in Gallo-Greek. After a small gap we find another name, in Greek letters, and significantly, a Greek verb, ANEOYNOC / EПOEI 'Aneunos made this'. This is the only example of a Greek verb found within the same frame as our Gaulish inscriptions. Then after another short gap we find a Gallo-Latin inscription: ELVONTIV / IEVRV ANEVNO / OCLICNO LVGVRIX / ANEVNICNO, which has been interpreted as a dedication 'Aneunos, son of Oclos, and Lugurix, son of Aneunos, dedicated this to Eluontios'. It is difficult to establish the relationship between this use of Gallo-Latin, Gallo-Greek and Greek within one object, and it may be that the 4-line inscription was added later than the others or by another person (it shows loss of final $-s$, unlike the others). Another text found in Saint-Germain-Source-Seine (RIG I, G-271; II.1, L-12) has a Gallo-Latin sentence ARIISIIQVANI ARIIOS IOVRVS LVCIIO NIIRTIICOMA followed by a Gallo-Greek maker's signature: $\triangle$ AГO $\Lambda$ ITOYC AYOWYT 'Dagolitus made this'. There are also several sites which offer both Gallo-Greek and Gallo-Latin texts: Alise-Sainte-Reine (RIG I, G-256-270; RIG II.1, L-13); Mont Beuvray (RIG I, G-235-255; II.2, L-82a-i); Roanne (RIG I, G-228-234; II.2, L-81a-d) and Vertault (RIG I, G-272-274; II.2, L-85). The Gallo-Latin corpus provides several sets of texts which are very closely associated with Latin and indicate bilingualism. The La Graufesenque graffiti on ceramic are perhaps the most famous of these: written in Latin, Gaulish or a mixture and dating mostly from the Neronian to late Flavian periods these couple of hundred texts are mainly firing lists for internal administration of the vast pottery. The texts list, for example, the information about a particular loading of the kiln: potters' names, types and sizes of vessels, quantities. It is clear from these texts that this mass production site was functionally bilingual. ${ }^{60} \mathrm{~A}$ group of two dozen inscriptions have also been found on spindle whorls, small objects used in the spinning process and, in these cases, made of bituminous schist from Autun. Again, the texts are in Latin (e.g. salve soror), Gaulish (MONI GNATHA GABI / BUĐĐVTON IMON)

60 For bilingualism at La Graufesenque, see Adams 2003; Blom 2012; Mullen 2013b, forthcoming. 
or a mixture (nata vimpi / vim pota). They seem to be short dedications for women, sometimes risqué. ${ }^{61}$

\subsection{Writing systems}

There are no major difficulties in reading the characters used to write the Gaulish language: either in Greek capitals or in Latin script (capital and cursive), though some Gaulish names written in Iberian script pose a few problems for transcription. ${ }^{62}$

The script for Gallo-Greek is relatively homogeneous and contains no letters which do not come directly from the Greek alphabet. The adoption of Greek script for the representation of Gaulish required some degree of phonological analysis, both of the donor and recipient language. In general terms, the graphemes used in Greek are employed to represent similar phonemes in Gaulish. In some cases graphemes are redundant and therefore not adopted into Gallo-Greek (e.g. Z, $\Phi, \Psi)$ ). The length of vowels in Gaulish is not systematically represented graphically. In fact, omega appears just ten times in $R I G$ I, and only three times in Southern Gaul. The use of eta is marginally more common and more evenly spread, but it is employed to notate both long and short vowels so may just be a stylistic feature. Gallo-Greek, however, appears to mark a difference between vowel qualities, with close and open $i$ represented by I, but open $i$ showing a preference for the notation EI. Similarly, two qualities of $u$ can be identified: close $u$ is represented by the digraph OY, whereas open $u$ is represented with $\mathrm{O} / \omega$ / OY. The semi-vowel /w/ generally receives the notation OY. In terms of the consonantal inventory, we sometimes find

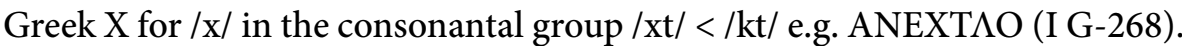
$\mathrm{N} \Gamma$ is occasionally used in Gallo-Greek e.g. KONГENNOMAPOC (Lejeune 1994 G-526) to replace $Г \Gamma$ in Greek for the velar nasal plus /g/, though $Г \Gamma$ is also found in Gallo-Greek e.g. ЕСКЕГГО (RIG I, G-13, 146, 154). The use of $\Gamma \Gamma$ indicates an understanding of Greek orthographic practices beyond simply learning the alphabet. The main adaptation required for Gallo-Greek was the representation of a phoneme in Gaulish, absent from Greek, whose exact phonological content has elicited much debate, mostly concerning its phonetic value in the Roman period, when it is referred to as 'tau gallicum' (Vergil Cat. 2). This sound is represented in Gallo-Greek by $\Theta(\Theta)$, but also by $T(T), C(C)$ and $\mathrm{C} \Theta$, and probably had no direct equivalent in Greek. Since a range of

61 For the spindle whorls, see Dondin-Payre 2005; Meid 1983.

62 Correa 1993; Ruiz Darasse 2010; Ruiz Darasse 2015. 
representations are employed in Gallo-Greek, it is possible that the sound was undergoing a process of change within Gaulish, as perhaps also indicated by the Gallo-Latin and Latin evidence.

\begin{tabular}{|c|c|}
\hline A & $\triangle A A A A A A$ A $\triangle 4$ \\
\hline B & $B B B B B B B B B D$ \\
\hline$\Gamma$ & rTT \\
\hline$\Delta$ & $\Delta \Delta \Delta \Delta \Delta \Delta$ \\
\hline $\mathrm{E}$ & $\in E E \in E \in E \in E$ \\
\hline $\mathrm{H}$ & $H$ \\
\hline$\Theta$ & $\theta \theta \theta$ \\
\hline I & 111 \\
\hline K & $k k K k k K k k K r$ \\
\hline$\Lambda$ & $\wedge \wedge \curlywedge \lambda$ \\
\hline M & $M M M M M M M M M$ \\
\hline $\mathrm{N}$ & NNNNNNNHNN \\
\hline$\Xi$ & $\equiv$ \\
\hline $\mathrm{O}$ & $000 \Delta$ \\
\hline$\Pi$ & $\pi$ \\
\hline $\mathrm{P}$ & PPPPQPPPPR \\
\hline$\Sigma$ & $(c \subset C \Sigma \in \Sigma \Sigma \Sigma$ \\
\hline $\mathrm{T}$ & $T T T T \neg T$ \\
\hline$Y$ & Y YYYYYYRTVY \\
\hline $\mathrm{X}$ & $x$ \\
\hline$\Omega$ & $\omega \| \ll \ll \ll$ \\
\hline
\end{tabular}

Table 1. Indicative types of letter forms used for Gallo-Greek, after RIG I (Mullen \& Ruiz Darasse 2018, table 6). 


\begin{tabular}{|c|c|c|}
\hline A & $A A \wedge \wedge A$ & 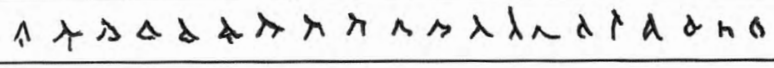 \\
\hline B & $B B B$ & $B B Z 622 \lambda<3266$ \\
\hline c & $(C$ & $<<2<c$ \\
\hline D & $D D$ & $D \partial \partial y \partial \partial y \partial$ \\
\hline$\ominus$ & $\theta$ & $\theta \theta$ \\
\hline E & EE II & $u u u$ \\
\hline $\mathrm{F}$ & & $L^{2}$ \\
\hline G & $G G$ & $a \&<s$ \\
\hline H & & h \\
\hline $1 / 1$ & II & Ils \\
\hline $\mathrm{k}$ & & $k$ \\
\hline L & $L$ & $1 ー L L \subset L L \zeta 2$ \\
\hline M & $M M$ & $\mu \nu \pi d \mu$ \\
\hline $\mathrm{N}$ & $\mathrm{NN}$ & NNNMMN \\
\hline o & 000 & $\triangle 04000$ a d ter \\
\hline $\mathrm{P}$ & P & ¿PPE \\
\hline a & $a$ & a \\
\hline R & $R R$ & $R, \lambda \lambda, 2 \approx z$ \\
\hline s & 55 & Sorse \\
\hline $\mathrm{T}$ & $T$ & $I \tau r I$ \\
\hline$u$ & V V & 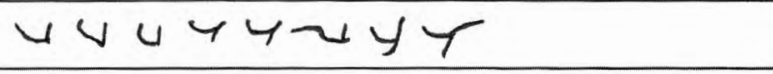 \\
\hline$x$ & $x$ & $x$ \\
\hline
\end{tabular}

Table 2. Indicative types of letter forms used for Gallo-Latin. The cursive forms are taken from Marichal 1988 (Mullen \& Ruiz Darasse 2018, table 7). 
The script forms of Gallo-Latin are more complicated, as Gaulish employs both Latin capitals, for use on lapidary output but also for stamps, rings, spindle whorls etc., and cursive Latin, the script Romans used for handwritten documents, for example in the firing lists from La Graufesenque. Cursive Latin is, for us at least, much harder to read and contains chronological, scribal and regional variation. Again, as with Gallo-Greek, the so-called 'tau gallicum' presents issues of notation since the sound it represents seems not to match directly anything in Latin. Early texts use a theta, sometimes doubled, though this is replaced by a range of options (e.g. barred d, double barred d, double unbarred $\mathrm{d}$, barred $\mathrm{d}+\mathrm{s}$, double s, double barred s) and the 'tau gallicum' occurs more often, for example in Gaulish names, in Latin inscriptions than in Gallo-Latin. The lack of consistency with the notation of this sound may again possibly reflect separate adoptions of the Roman script to write Gaulish, or at least a lack of strong standardization and schooling. Since Gallo-Latin uses two letter forms from Gallo-Greek: $\chi$ and $\theta$, it is likely that knowledge of that epigraphy may have circulated at the time when Gallo-Latin was being created.

\subsection{Personal names}

Names have been key evidence in the scholarship on Gaulish. Often, only a simple idionym is mentioned. There are several examples of diminutives or hypocoristic suffixation (in -illo for example, or by repetition). There does not seem to have been a specific designation for certain social categories, such as slaves or freedmen, in the Celtic world and women's names do not seem to have been treated differently from those of men.

The Continental Celtic system of marking filiation is by an individual name with patronymic genitive, e.g. Asiatícon Adđedillí (Chamalières, RIG II.2, L-100), or adjectival suffix, e.g. Aneunos Oclicnos (Genouilly), RIG II.1, L-4b). There may be regional variation: Gallo-Latin uses both the simple genitive (Doiros Segomari RIG II.2, L-133, Couchey) and the suffixation method (Andecamulos Toutissicnos, RIG II.1, L-11, Nevers, with a suffix in -icnos); Gallo-Greek relies only on patronymic adjectives, for example, in -ios (CEKEIOC

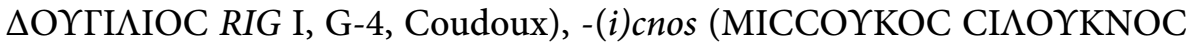
RIG I, G-119), -akos (KABIPOC OYIN $\triangle \mathrm{IAKOC} \mathrm{RIG} \mathrm{I,} \mathrm{G-118)} \mathrm{(fig.} \mathrm{5).}$ 
Fig. 5. $19^{\text {th }}$ century drawing by Héron de Villefosse of two Gallo-Greek inscriptions on stelae from Glanum (RIG I, G-68, 69), showing personal names with patronymics in -eos and -ios.

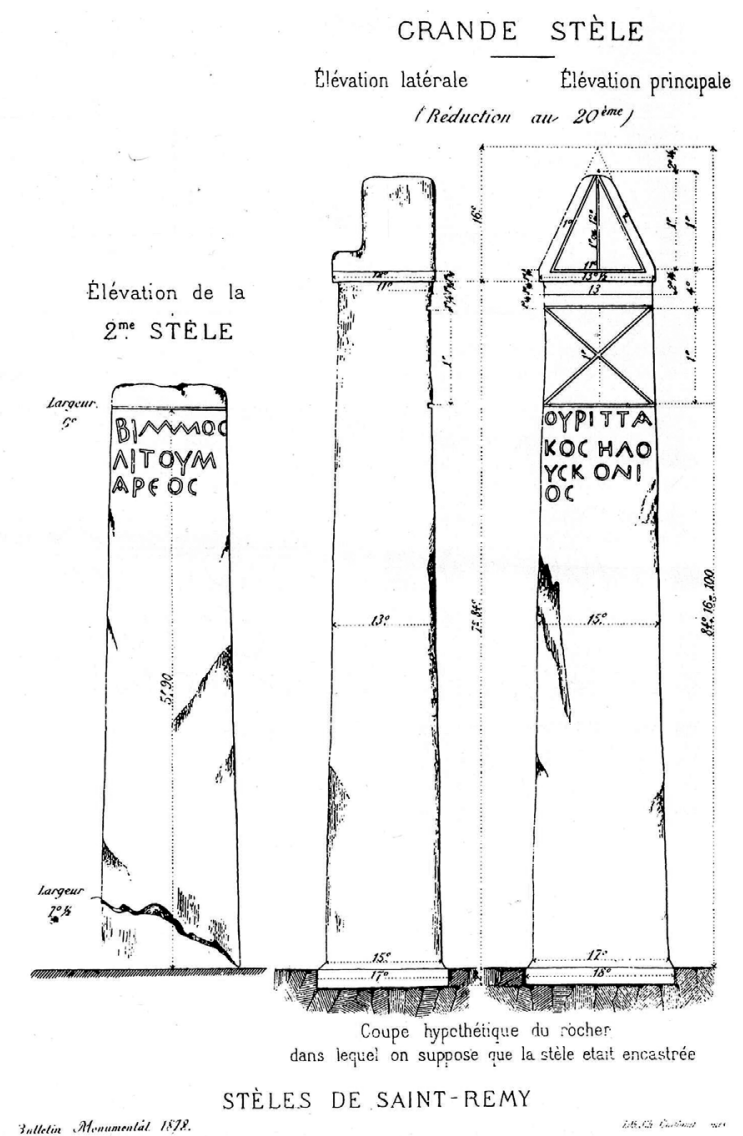

In Roman Gaul peregrini (free-born provincials without Roman citizenship) in Latin texts tended to use the formula of idionym followed by patronymic genitive, with or without Latin filiation marker, and Celtic names can be found extensively in these naming practices, e.g. Secundus [Latin] Dannomari [Celtic] f(ilius) from Nîmes (CIL XII, 3884). Roman duo nomina and tria nomina naming formulae are also found containing Celtic names alongside Latin ones, e.g. Caius Iulius Vercondaridubnus (Livy, Per. 139). Indeed we find a mixture of naming practices, both nomenclature and formulae in Gaulish inscriptions of the Roman period. The Gallo-Latin Chamalières lead tablet (RIG II.2, L-100), for example, includes onomastic material indicative of a transitional period: C. Lucion Floron Nigrínon adgarion, Aemilíon Paterin(on), Claudíon Legitumon, Caelion Pelign(on), Claudío Pelign(on), Marcion Victorin(on), Asiatícon Adđedillí. The Latin names in the tria nomina and duo nomina formulae are mixed with Gaulish morphology (accusative singular in -on), names and epithets. 
The final character, Asiatícon Ađđedillí, is identified in Gaulish/peregrine manner with a non-Gaulish personal name and a Gaulish patronymic.

The largely earlier Gallo-Greek inscriptional record offers less evidence of the results of language contact, with the names almost entirely Gaulish and displayed in the form single name or single name plus patronymic adjective. One interesting set of Gaulish names which do show language contact phenomena can be found in the $2^{\text {nd }}$ to $1^{\text {st }}$ century BC Greek graffiti on ceramic from the sanctuary of Aristaios ( $\$ 1.6)$. Here the Gaulish names are found, not in Gallo-Greek format, but following the pattern of idionym plus patronymic genitive e.g. РЕГОА $О$ OC OYE $\Lambda$ AYNOY (IGF 68-35).

None of the non-Gaulish names in the Gallo-Greek inscriptions published to date is certainly Greek. The possible instances of non-Gaulish names can all be linked to the Italian peninsula: KOPNH $\Lambda$ IA (Glanum (Bouches-duRhône), RIG I, G-65, Latin name Cornelia); ГAIOC (Gaujac (Gard), I, G-198, Latin name Gaius); ГAIIA (Bibracte (Bourgogne), I, G-243, Latin name Gaia); CKOYPPA (Cavaillon (Vaucluse), I, G-141, Latin name Scurra); EKI $\Lambda$ IOC P[?]OYMAN[I/E?]OC (Collias (Gard), I, G-183, Latin name Romanus); OYENITOOYTA KOYA $\triangle$ POYNIA (Ventabren (Bouches-du-Rhône), I G-106, Latin name Quadron(i)us), KAEIOC IN $\Delta$ OYTI $\Lambda$ O (Velleron (Vaucluse), Bats 2011a, Latin name Gaius).

\section{Current problems and main future challenges}

\subsection{Linguistic}

The Gaulish language does not pose significant issues of comprehension or broad categorization - there is no debate over its Celticity. Even though we do not have enough continuous written Gaulish to be able to reconstruct the language completely, we understand Gaulish much better than non-Indo-European fragmentary languages such as Etruscan and Iberian through our knowledge of Indo-European linguistics and later Celtic (insular) languages, even if there is no coincidence in time or space in the documentation. The precise phonetic realization of the so-called 'tau gallicum', which we think is some sort of affricate, has been the subject of debate given the multiple renditions in script and its appearance also in Latin inscriptions. ${ }^{63}$ We know

63 Corinna Salomon undertook an AELAW short-term scientific mission in 2019 with LatinNow to collect the attestations and to explore the possible diachronic and regional realities. 


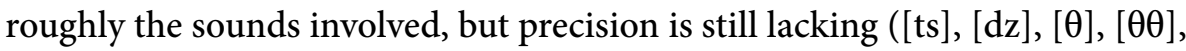
$[\mathrm{t} \theta],[ð],\left[\mathrm{t}^{\mathrm{h}}\right],[\theta \mathrm{s}],[\mathrm{s}]$ have all been suggested). ${ }^{64}$ There is also uncertainty in the reconstruction of patterns of accentuation and how these change over time and how they may, or may not, relate to the Latin spoken in Gaul.

Despite our comparatively good grasp of this ancient language, comprehensibility of many inscriptions continues to be an issue. We understand a great deal of the language but cannot always make complete sense of more complicated texts and the exact translation is always precarious. For long texts with more elaborate syntax (e.g. the Larzac tablets or the Châteaubleau tile) and those which do not correspond to pre-established forms (such as the dedications with dede bratou dekantem), matters are complicated. In addition, scriptio continua often makes it difficult to identify coherent syntactic sequences: often no word dividers or spaces are used. Even when we can segment the texts properly, we cannot always be certain whether we have correctly identified the parts of speech.

Despite unanimity on Gaulish's status as a Celtic language, there continues to be much debate about the interrelationships of the Celtic branch of the Indo-European family tree (fig. 6). One well-established categorization of the languages based on linguistic criteria groups them into so-called P- and Q- Celtic, based primarily on the treatment of Proto-Indo-European labio-velar, ${ }^{*} \mathrm{k}^{\mathrm{w}}$ - and the reflexes of the syllabic nasals as /aN/ or /eN/. This linguistic division divides the Continental Celtic varieties, with Gaulish grouped with P-Celtic and Celtiberian with Q- ${ }^{65}$ Following this division, the Celtiberian language appears to share more features with Irish than with the language of its immediate neighbours in southern Gaul, and the Brittonic languages of the British Isles, British Celtic and its descendants Welsh, Cornish and Breton, would be closer to Gaulish than to Irish. Many Celticists have rejected this $\mathrm{P}-/ \mathrm{Q}$ - division, arguing that the differing development of the labio-velars is unimportant for phylogenetic classification and that the reflex of the syllabic nasals was /aN/, with examples of /eN/ secondary. As Eska has stated '[w]hat were the two traditional linchpins upon which the phylogeny of the Celtic language family was based, in fact, are not diagnostic of anything at all. ${ }^{66}$ There is more work to be done on Celtic interrelations, and the Gaulish record has an important role to play in this analysis.

64 See, for example, Eska 1998.

65 Lewis \& Pedersen 1937, $\$ 1$.

66 Eska 2017, 1265. 


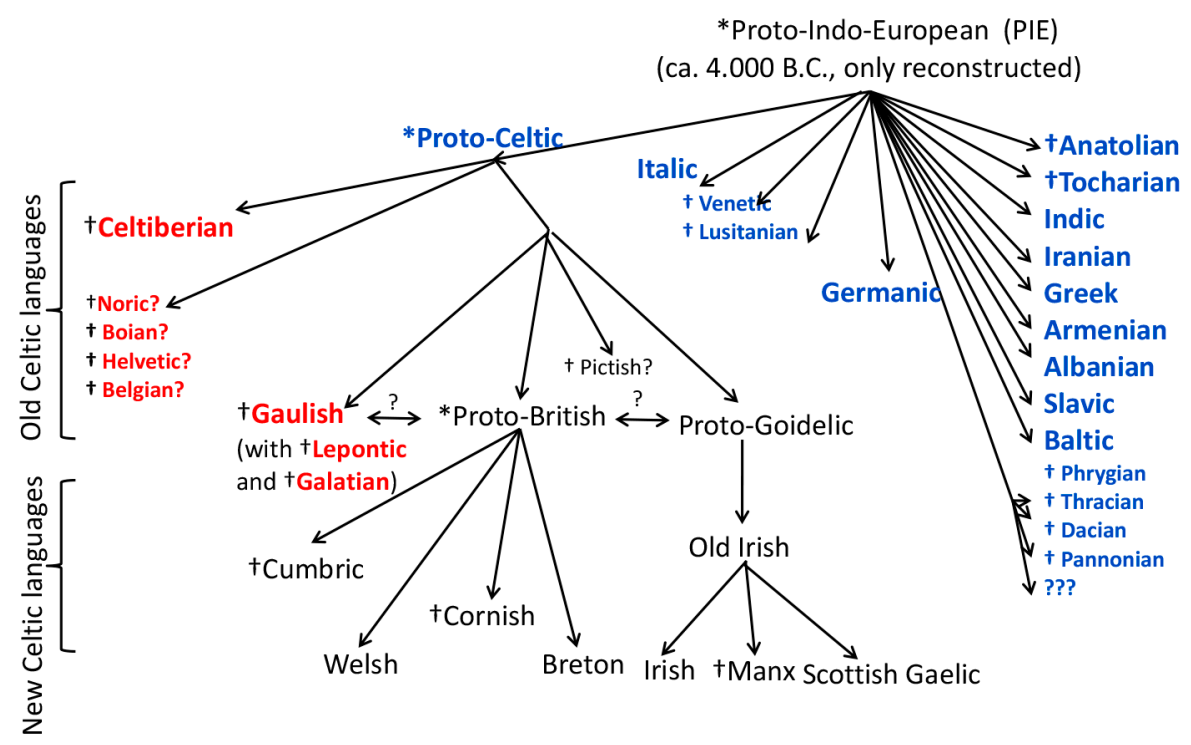

Fig. 6. D. Stifter's simplified depiction of the relationships between Celtic languages within the Indo-European family tree.

The nature of a Gallo-Brittonic group, for example, must continue to be assessed. Insular Celtic is split into two groups: Irish, Scottish Gaelic, Manx in the Goidelic group and Welsh, Cornish and Breton in the Brittonic group. The Gallo-Brittonic node of the Celtic family would include the ancient Celtic language of Britannia, British Celtic, the ancestor of the Brittonic Insular Celtic languages, and Gaulish. Many of the linguistic features ascribed to this group, however, could be the result of contact and " $[t]$ he evolution of the dual system of verbal flection shared by Goidelic and Brittonic, evidence for which is completely lacking in Transalpine Celtic, on the other hand, is so unusual and distinctive as to guarantee the diagnosis of an Insular Celtic node in the Celtic family tree". ${ }^{67}$ How these two groupings - Gallo-Brittonic and Insular Celtic - can be reconciled constitutes important work for linguists.

The question of dialects within Gaulish is also far from being resolved. Given the large area over which Gaulish was spoken there would have been dialectal variation across social, geographical and chronological dimensions. Many dialectal variants across Gaul may have mapped onto local identities which we cannot capture. Unfortunately, the fragmentary nature of the corpus 
and our incomplete understanding of the remains mean that we could never reconstruct the dialects in any detail, ${ }^{68}$ though work is underway to advance our knowledge.

\subsection{Epigraphic}

A key area for future work might be in considering further the place of origin(s) of both Gallo-Greek and Gallo-Latin. As we saw above ( $\$ 1.5$ ), the image of a Gallo-Greek epigraphy created at Marseille has been questioned. Similarly, the region of the origin(s) of Gallo-Latin is uncertain. There are arguably no Gallo-Latin stone inscriptions from Southern Gaul. The two which normally are counted as Gallo-Latin are both from the Bouches-duRhône: VECTIT[... BIRACI[... (RIG II.1, L-1, Ventabren, second third of $1^{\text {st }}$ century BC) and BOVDILATIS LEMISVNIA (L-2, Coudoux, second third of $1^{\text {st }}$ century BC) (fig. 7). ${ }^{69}$ The second inscription might be more securely assigned to Gaulish as it contains the Gaulish patronymic suffix -ia. However, the Ventabren stele does not provide any diagnostic features, and may well be Latin (containing Gaulish names). In fact both may have been intended to be Latin, but written by Celtic-speaking groups not conversant with Latin epigraphic conventions. There are similarly very few clear examples of non-lapidary Gallo-Latin from the south. ${ }^{70}$

A particularly important topic is that of the dating of Gallo-Latin. The corpus has traditionally been dated from the Caesarian to the early imperial period - in part based on assumptions concerning the cultural and lingusitic context of the texts. Since several of the more recently found texts with firm archaeological datings push beyond the $1^{\text {st }}$ century $\mathrm{AD}$ it will be useful to reconsiderer the dating of every text systematically, a task which is a key part of the RIIG project.

\section{Lambert 2018, 19.}

69 See the discussion in RIG II.1, p. 63-68 and Lejeune 1977.

70 These include: one inscription from Orange (RIG II.2, L-18), about which Lambert notes 'il ne s'agit pas d'une véritable inscription gallo-latine, mais de la citation, en contexte latin, d'un mot gaulois' (RIG II.2, 36) (this is cited on a stone monument, but Lambert considers it only 'secondarily lapidary'); the Amélie-les-Bains tablets (L-97), which possibly contain elements of Gaulish in Latin script, though caution must be exercised as this is a magical text known only through transcriptions; and perhaps one or two fragmentary graffiti whose linguistic affiliations are uncertain (see Bats 2011a, 220, for possible examples). 


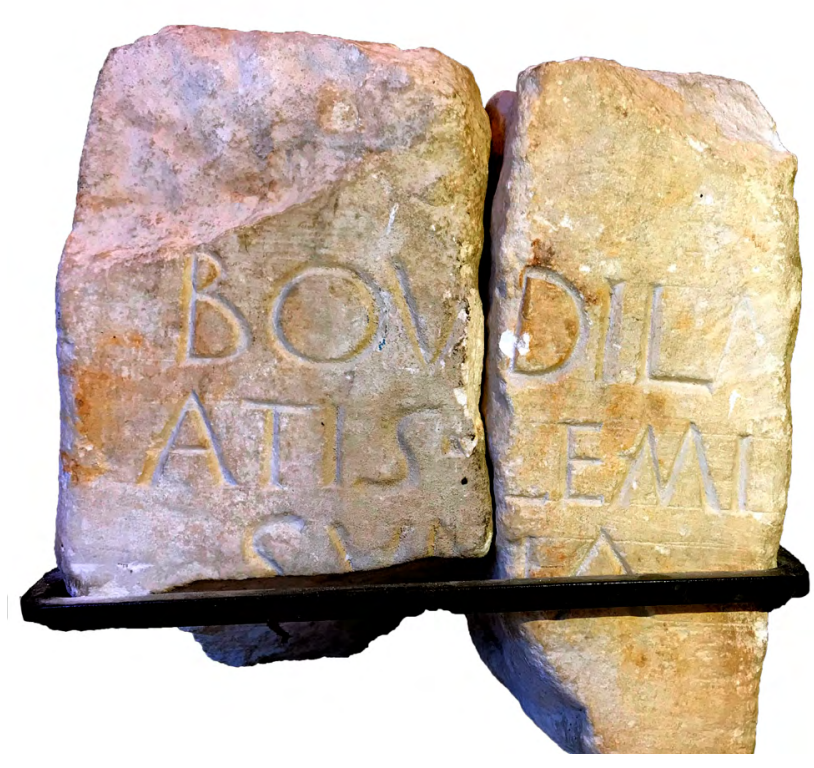

Fig. 7. The Gallo-Latin, or possibly Latin, inscription from Coudoux (RIG II.1, L-2) (photo: Ch. Mullen).

Traditionally Gallo-Greek epigraphy was considered an aspect of Hellenization of the Celtic-speaking 'barbarians'. Increasingly scholars have interpreted the inscriptions as expressions of local identity which do not necessarily entail any straightforward, wholesale adoption of Greek culture. ${ }^{71}$ Intense contacts with the Mediterranean environment, especially the Italian peninsula, and not just Greek cultures, have recently been shown to have had an impact in the adoption and use of Gallo-Greek, as has increased settlement fixity and the increasing economic strength of the indigenous communities. Archaeologists, historians and linguists have not always worked together on the possible contextual meanings of the epigraphy, a key focus for the future might be in working together rather than creating different explanatory models.

\subsection{Writing systems}

Work remains to be done on the palaeographical aspect of the inscriptions: the tables of scripts above are based on those of Lejeune and, for cursive Latin, those of Marichal in his study of La Graufesenque, both published in the 1980s. They would therefore benefit from updating, starting with a systematic exploration of recent finds, though we do not expect that this work

71 For distinctive patterns of adoption of other Greek cultural practices, for example, bodily adornment and the consumption of wine, garum and olive oil, see Dietler 1999, 2010. 
would add any radical change to our knowledge. A precise palaeography of Gaulish inscriptions will be one aspect of the RIIG project.

\subsection{Edition and publication}

The Gaulish editions are not beset with issues of transcription and competing editorial norms that trouble some other epigraphies. However Gallo-Latin has been probably less systematically published than Gallo-Greek. One problem is that a few Latin letters on pottery, even if they contain a Gaulish name, will often not be assigned to Gallo-Latin but rather to Latin (and commonly not published), whereas more of the inscriptions with Greek letters are published as Gallo-Greek if they contain Celtic elements. It is difficult to be sure of the exact number of Gaulish inscriptions that have not been published. Many examples, especially on non-lapidary materials and in cursive script, are not necessarily identified, and, even if recognized, may not make it to the appropriate experts for publication, some remaining in private collections or in local repositories. Many of the graffiti from sites of Celtic-speaking communities were not published by Lejeune if they only contained a couple of letters as it is difficult to be sure of their linguistic affiliation, but many of these may be Gaulish.

In addition to the incomplete publication of texts, the main Gaulish corpora are now out-of-date. There are few recent photos, the current location of inscribed objects is often not recorded, the material supports are not always clearly identified and there may have been several re-readings since the initial publications. To try to improve this situation, we have launched a project, drawing on an international team, to produce an Open Access, Linked Open Data, online collection of all known Gaulish inscriptions (RIIG). The revised and expanded textual edition will be produced in EpiDoc format (TEI-XML) and will take into account the material and broader context of the texts and will open a new phase in modern studies of Gaulish. 


\section{$\begin{array}{llllllllllll}\mathbf{B} & \mathbf{I} & \mathbf{B} & \mathbf{L} & \mathbf{I} & \mathbf{O} & \mathbf{G} & \mathbf{R} & \mathbf{A} & \mathbf{P} & \mathbf{H} & \mathbf{Y}\end{array}$}

BDH: Hesperia, Banco de datos de Lenguas Paleohispánicas, http://hesperia.ucm.es/.

IGF: J.-C. Decourt, Inscriptions grecques de la France, (Travaux de la maison de l'Orient et de la Méditerranée), Lyon 2004.

RIG I: M. Lejeune, Recueil des inscriptions gauloises. I, Textes gallo-grecs, (Gallia Supplément, 45), Paris 1985.

RIG II.1: M. Lejeune, Recueil des inscriptions gauloises. II, fasc. 1, Textes gallo-étrusques, textes gallo-latins sur pierre, (Gallia Supplément 45), Paris 1988.

RIG II.2: P.-Y. Lambert, Recueil des inscriptions gauloises. II, fasc. 2, Textes gallo-latins sur instrumentum, (Gallia Supplément, 45), Paris 2002.

RIG III: P.-M. Duval \& G. Pinault, Recueil des inscriptions gauloises III, Coligny, Villards d'Héria. Les Calendriers, vol. 1, Paris, (Gallia Supplément, 45), Paris 1986.

RIG IV: J.-B. Colbert de Beaulieu \& B. Fischer, Recueil des inscriptions gauloises IV. Les légendes monétaires, (Gallia Supplément, 45), Paris 1998.

Adams 2003: J. Adams, Bilingualism and the Latin Language, Cambridge 2003.

Ball \& Müller 2010: M. Ball and N. Müller (eds.), The Celtic languages, London 2010.

Bats 1988: M. Bats, "La logique de lécriture d’une société à l'autre en Gaule méridionale protohistorique", RAN 21/1, 1988, 121-148.

Bats 2004: M. Bats, "Grec et gallo-grec : les graffites sur céramique aux sources de l'écriture en Gaule méridionale (II ${ }^{\mathrm{e}} \mathrm{I}^{\mathrm{er}}$ s. av. J.-C.)”, Gallia 61/1, 2004, 7-20.

Bats 2011a: M. Bats, "Emmêlements de langues et de systèmes graphiques en Gaule méridionale (VI ${ }^{\mathrm{e}} \mathrm{I}^{\mathrm{er}}$ siècle av. J.-C.)", in: C. Ruiz Darasse and E. R. Luján Martínez (eds.), Contacts linguistiques dans l'Occident méditerranéen antique, Madrid 2011, 197-226.

Bats 2011b: M. Bats, "Entre Ibères et Celtes : l'écriture à Ensérune dans le contexte de la Gaule du Sud (Ve-IIe s. av. J.-C.)”, in: E. R. Luján Martínez and J. L. García Alonso (eds.), A greek man in the Iberian street, Innsbruck 2011, 129-137.

Bats 2012: M. Bats, "Les dédicants gaulois du sanctuaire d’Aristée de la chôra d'Olbia de Provence (Hyères, Var) connaissaient-ils le gallo-grec ?", in: A. Hermary and G. Tsetskhladze (eds.), Studia celtica classica et romana Nicolae Szabo septuagesimo dedicata, Budapest 2012, 51-54.

Belfiore 2015: V. Belfiore, "Graffiti etruschi dalla Gallia e il piombo di Pech Maho : alcune questioni paleografiche e contenutistiche", in: R. Roure, C. Aranegui Gascó, P. Boissinot and A. Bouet (eds.), Contacts et acculturations en Méditerranée occidentale: hommages à Michel Bats, Arles-Aix-en-Provence 2015, 537-543.

Bernard, Collin-Bouffier \& Tréziny 2010: L. Bernard, S. Collin-Bouffier and H. Tréziny, "Grecs et indigènes dans le territoire de Marseille", in: H. Tréziny (ed.), Grecs et indigènes de la Catalogne à la Mer Noire, Paris 2010, 131-145.

Blom 2009: A. H. Blom, "Lingua gallica, lingua celtica: Gaulish, Gallo-Latin, or GalloRomance?”, KF 4, 2009, 7-54. 
Blom 2012: A.H. Blom, "Language at La Graufesenque: the evidence of the potters' graffiti", KF 5, 2012, 7-47.

Briquel et al. 2006: D. Briquel, L.-F. Gantès, J. Gran-Aymerich and P. Mellinand, "Marseille: nouvelles découvertes grecques et étrusques”, Archéologia 432, 2006, 36-43.

Champion 2016: T. Champion, "Britain before the Romans", in: M. Millett, L. Revell and A. Moore (eds.) The Oxford Handbook of Roman Britain, Oxford 2016, 150-178.

Collis 2003: J. Collis, The Celts. Origins, myths \& inventions, Stroud 2003.

Colonna 1980: G. Colonna, "Graffiti etruschi in Linguadoca”, SE, 48, 1980, 181-185.

Colonna 2006: G. Colonna, “A proposito della presenza etrusca nella Gallia meridionale”, in: S. Gori and M. C. Bettini (eds.), Gli Etruschi da Genova ad Ampurias, Pisa 2006, 657-678.

Correa 1993: J. A. Correa, "Antropónimos galos y ligures en inscripciones ibéricas", in: I. J. Adiego, J. Siles and J. Velaza (eds.), Studia Palaeohispanica et Indogermanica J. Untermann ab amicis hispanicis oblata, Barcelona 1993, 101-116.

Déchelette 1908-1914: J. Déchelette, Manuel d’archéologie préhistorique, Celtique et galloromaine, Paris 1908-1914.

De Hoz 2008: J. de Hoz, "A Celtic personal Name on an Etruscan inscription from Ensérune, previously Considered iberian (MLH b.1.2b)", in: J. L. García Alonso (ed.), Celtic and other Languages in Ancient Europe, Salamanca 2008, 17-27.

De Hoz 2011a: J. de Hoz, Historia lingüística de la Península Ibérica en la Antigüedad II. El mundo ibérico prerromano y la indoeuropeización, Madrid 2011.

De Hoz 2011b: J. de Hoz, "Las funciones de la lengua ibérica como lengua vehicular", in: E. R. Luján Martínez \& C. Ruiz Darasse (eds.), Contacts linguistiques dans l'Occident méditerranéen antique, Madrid, Madrid 2011, 27-64.

Delamarre 2007: X. Delamarre, Les noms de personnes celtiques dans l'épigraphie classique, Paris 2007.

Delamarre 2012: X. Delamarre, Noms de lieux celtiques de l'Europe ancienne, Paris 2012.

Delamarre 2018: X. Delamarre, Dictionnaire de la langue gauloise: une approche linguistique $d u$ vieux celtique continental, Paris $2018^{3}$ [1st ed. 2001].

Deroc 1983: A. Deroc, Les monnaies gauloises d’argent de la Vallée du Rhône, Paris 1983.

Dietler 1999: M. Dietler, "Consumption cultural frontiers, and identity: anthropological approaches to greek colonial encounters", in: A. Stazio and S. Ceccoli (eds.), Confini e frontiere nella Grecitá d'occidente, Taranto 1999, 475-501.

Dietler 2010: M. Dietler, Archaeologies of colonialism: consumption, entanglement, and violence in ancient Mediterranean France, Berkeley 2010.

Dondin-Payre 2005: M. Dondin-Payre, "Épigraphie et acculturation: l'apport des fusaïoles inscrites", in: J. Desmulliez and C. Hoët-van Cauwenberghe (eds.) Le monde romain à travers l'epigraphie: méthodes et pratiques, Lille 2005, 133-146.

Dottin 1918 : G. Dottin, La langue gauloise. Grammaire, Textes et glossaire, Paris 1918.

Eska 1997: J. F. Eska, “Allophony, Chamalières eđđic, and related matters", ZCP 49-50, 1997, 170-178.

Eska 1998: J. F. Eska, “Tau Gallicum”, SC 32, 1998, 115-127.

Eska 2007: J. F. Eska, "On basic configuration and movement within the Gaulish clause", in: P.-Y. Lambert and G.-J. Pinault (eds), Gaulois et celtique continental, Genève 2007, 215229. 
Eska 2017: J. F. Eska, “The Dialectology of Celtic”, in: J. Klein, B. Joseph, M. Fritz and M. Wenthe (eds), Handbook of Comparative and Historical Indo-European Linguistics, vol. II, Berlin 2017, 1264-1274.

Estarán 2016: M. J. Estarán, Epigrafía bilingüe del Occidente romano: el latín y las lenguas locales en las inscripciones bilingües y mixtas, Zaragoza 2016.

Evans 1967: D. E. Evans, Gaulish Personal Names. A study of some Continental Celtic formations, Oxford 1967.

Feugère \& Py 2011: M. Feugère and M. Py, Dictionnaire des monnaies découvertes en Gaule méditerranéenne (530-27 avant notre ère), Montagnac-Paris 2011.

Giffault \& Coupry 1990: M. Giffault and J. Coupry, "Giens", in: P. Arcelin (ed), Voyage en Massalie: 100 ans d'archéologie en Gaule du Sud, Marseille 1990, 214-219.

Gorgues 2010: A. Gorgues, Économie et société dans le Nord-Est du domaine ibérique (III ${ }^{e} \mathrm{I}^{2 r}$ s. av. J.-C.), Madrid 2010.

Gorrochategui 1984: J. Gorrochategui, Estudio sobre la onomástica indígena de Aquitania, Bilbao 1984.

Gran-Aymerich 2006: J. Gran-Aymerich, "Les Étrusques et l'extrême Occident (VII ${ }^{\mathrm{e}}-\mathrm{V}^{\mathrm{e}}$ siècles av. J.-C.) : regards sur l'Isthme gaulois et la péninsule Ibérique", in: G. M. Della Fina (ed), Gli Etruschi e il Mediterraneo. Commerci e politica, Roma 2006, 253-283.

Häussler 2002: R. Häussler, "Writing Latin: From Resistance to Assimilation. Language, culture and society in Italy and Gaul", in: A. Cooley (ed), Becoming Roman, Writing Latin, Portsmouth, RI 2002, 61-76.

Häussler 2008: R. Häussler, Romanisation et épigraphie: études interdisciplinaires sur l'acculturation et l'identité dans l'Empire romain, Montagnac 2008.

Hiriart 2017: E. Hiriart, Catalogue des monnaies celtiques. 2, Les monnaies à la croix, Paris 2017.

Holder 1896-1913: A. Holder, Alt-Celtischer Sprachschatz, Leipzig 1896-1913.

Lambert 1992: P.-Y. Lambert, "Diffusion de lécriture gallo-grecque en milieu indigène”, in: M. Bats et alii (eds), Marseille grecque et la Gaule, Aix 1992, 289-294.

Lambert 1997: P.-Y. Lambert, "Lépigraphie gallo-grecque”, in: Actes $d u X^{e}$ congrès international d'épigraphie grecque et latine, Nîmes 4-9 octobre 1992, Paris 1997, 35-50.

Lambert 2003: P.-Y. Lambert, "Les inscriptions gallo-grecques parues depuis les Textes gallogrecs de Lejeune, M. (1985)”, ÉC 35, 2003, 169-179.

Lambert 2008: P.-Y. Lambert, "Recueil des inscriptions gauloises. II, 2: notes de compléments", ÉC 36, 2008, 103-113.

Lambert 2018: P.-Y. Lambert, La langue gauloise, Paris $2018^{3}$ [1st ed. 1994].

Lambert \& Pinault 2007: P.-Y. Lambert and G.-J. Pinault (ed.), Gaulois et celtique continental, Geneva 2007.

Lejeune 1960: M. Lejeune, “À propos d’un plomb inscrit d'Elne”, REA 62/1-2, 1960, 62-79.

Lejeune 1977: M. Lejeune, "La romanisation des anthroponymes indigènes d'Italie", in: P.-M. Duval and H.-G. Pflaum (eds.), L'onomastique Latine, Paris 1975, 35-41.

Lejeune 1983: M. Lejeune, "Vieille-Toulouse et la métrologie ibérique”, RAN 16, 1983, 28-37.

Lejeune 1994: M. Lejeune, “Compléments gallo-grecs: Bouc-Bel-Air; Beaucaire; Nîmes”, ÉC 30, 1994, 181-190.

Marichal 1988: R. Marichal, Les graffites de la Graufesenque, Paris 1988.

Meid 1983: W. Meid, "Gallisch oder Lateinisch? Soziolinguistische and andere Bemerkungen zu populären gallo-lateinischen Inschriften”, ANRW 29/2, 1983, 1019-1044. 
Meid 2014: W. Meid, Gaulish inscriptions: their interpretation in the light of archaeological evidence and their value as a source of linguistic and sociological information, Budapest 2014.

Meissner 2009-2010: T. Meissner, “Das Hieronymuszeugnis und der Tod des Gallischen”, ZCP 57, 2009-2010, 107-112.

Moret, Ruiz Darasse \& Verrier 2015: P. Moret, C. Ruiz Darasse \& G. Verrier, "Ibère, Grec et Latin à Toulouse à la fin du II ${ }^{e}$ s. a. C. Nouvelles inscriptions sur céramique du site de la ZAC Niel", Gallia 72/2, 2015, 403-416.

Mullen 2007: A. Mullen, "Evidence for written Celtic from Roman Britain: a linguistic analysis of Tabellae Sulis 14 and 18", SC 41, 2007, 31-45.

Mullen 2013a: A. Mullen, Southern Gaul and the Mediterranean: multilingualism and multiple identities in the Iron Age and Roman periods, Cambridge 2013.

Mullen 2013b: A. Mullen, "The language of the potteries: communication in the production and trade of Gallo-Roman terra sigillata", in: M. Fulford \& E. Durham (eds), Seeing Red: new economic and social perspectives on terra sigillata, London 2013, 97-110.

Mullen forthcoming: A. Mullen, “Transformations de la Gaule sous l'Empire romain: une culture de l'écrit au service de la production de masse", in: N. Moncunill \& M. ColtelloniTranoy (ed.), La culture de l'écrit en Méditerranée occidentale à travers les pratiques épigraphiques, Paris forthcoming.

Mullen \& Ruiz Darasse 2018: A. Mullen and C. Ruiz Darasse, Gaulish. Language, writing, epigraphy, Zaragoza 2018.

Mullen \& Ruiz Darasse 2019: A. Mullen and C. Ruiz Darasse, Galo. Lengua, escritura, epigrafía, Zaragoza 2019.

Muret \& Chabouillet 1983: E. Muret and A. Chabouillet, Catalogue des monnaies gauloises de la Bibliothèque nationale, Paris 1983.

Olmsted 1992: G. Olmsted, The Gaulish calendar: a reconstruction from the bronze fragments from Coligny, Bonn 1992.

Py 1995: M. Py, "Les Étrusques, les Grecs et la fondation de Lattes", in: P. Arcelin et al. (eds), Sur les pas des Grecs en Occident, Paris 1995, 261-276.

Py 2012: M. Py, Les Gaulois du Midi de la fin de l'âge du bronze à la conquête romaine, Paris 2012.

Raybould \& Sims-Williams 2009: M. E. Raybould and P. Sims-Williams, Introduction and supplement to the Corpus of Latin inscriptions of the Roman Empire containing Celtic personal names, Aberystwyth 2009.

Ruiz Darasse 2010: C. Ruiz Darasse, "Les Ibères en Languedoc: l'onomastique celtique d'Ensérune en écriture paléohispanique”, PalHisp 10, 2010, 335-354.

Ruiz Darasse 2015: C. Ruiz Darasse, "Au cœur des contacts linguistiques du Midi gaulois : langue et écriture paléohispaniques", in: D. Briquel and F. Briquel Chatonnet (ed.), Écriture et communication. $139^{\circ}$ Congrès national des sociétés historiques et scientifiques, Paris 2015, 58-65.

Ruiz Darasse 2020: C. Ruiz Darasse, “Dans une écriture et dans une autre. Quelques inscriptions du Midi gaulois", in: C. Ruiz Darasse (ed.), Comment sécrit l'autre ? Sources épigraphiques et papyrologiques dans le monde méditerranéen antique, Bordeaux 2020.

Ruiz Darasse forthcoming: C. Ruiz Darasse, “By any other name': Celtic names in palaeohispanic script. The case of Western Languedoc", in: G. Kloss and G. Broderick (ed.), Kelten, Römer, Griechen. Sprach- und Kulturkontakte im Römischen Reich und seinem Umfeld, Heidelberg forthcoming.

Russell 1995: P. Russell, An introduction to the Celtic languages, London 1995. 
Schrijver 1997: P. Schrijver, Studies in the History of Celtic Pronouns and Particles, Maynooth 1997.

Schmidt 1957: K.-H. Schmidt, "Die Komposition in gallischen Personennamen”, ZCP 26/1, 1957, 161-301.

Simón 2013: I. Simón Cornago, Los soportes de la epigrafía paleohispánica: inscripciones sobre piedra, bronce y cerámica, Zaragoza 2013.

Sims-Williams 1998: P. Sims-Williams, “The Celtic languages”, in: A. Giacalone Ramat and P. Ramat (ed.), The Indo-European languages, London 1998, 345-379.

Sims-Williams 2006: P. Sims-Williams, Ancient Celtic place-names in Europe and Asia Minor, Oxford-Boston 2006.

Untermann 1975-1997: J. Untermann, Monumenta Linguarum Hispanicarum, Wiesbaden 1975-1997.

Untermann 1992: J. Untermann “Quelle langue parlait-on dans l'Hérault pendant l'Antiquité?”, RAN 25, 1992, 19-27.

Vidal \& Magnol 1983: M. Vidal and J.-P. Magnol, "Les inscriptions peintes en caractères ibériques de Vieille-Toulouse", RAN 16, 1983, 11-28.

Whatmough 1970: J. Whatmough, The Dialects of Ancient Gaul, Cambridge MA 1970 [19491951].

Zavaroni 2007: A. Zavaroni, On the structure and terminology of the Gaulish calendar, Oxford 2007. 